\title{
Improved Surface Wettability of Water by Applying SiC/Ti6Al4V Coatings on Carbon/Carbon Composites
}

\author{
Lei-Lei Zhang, He-Jun Li, Ke-Zhi Li, Yu-Lei Zhang, Jin-Hua Lu, Sheng Cao, \\ Xue-Ni Zhao, and Zi-Bo He
}

State Key Laboratory of Solidification Processing, Northwestern Polytechnical University, Xian 710072, China

Correspondence should be addressed to Lei-Lei Zhang; zw1121@yahoo.com.cn

Received 5 December 2012; Accepted 7 March 2013

Academic Editor: Philip Harrison

Copyright (c) 2013 Lei-Lei Zhang et al. This is an open access article distributed under the Creative Commons Attribution License, which permits unrestricted use, distribution, and reproduction in any medium, provided the original work is properly cited.

\begin{abstract}
$\mathrm{SiC} / \mathrm{Ti} 6 \mathrm{Al} 4 \mathrm{~V}$ coatings were applied on carbon/carbon composites to improve the surface wettability of water. SiC interlayers were preprepared by pack cementation to bond both the carbon/carbon composites and the Ti6Al4V, and then the Ti6Al4V coatings were applied by magnetron sputtering technique. The morphology and crystalline of the SiC/Ti6Al4V coatings were analyzed by scanning electron microscopy, energy dispersive spectroscopy, and X-ray diffraction. The surface wettability of the coatings was tested by video-based contact angle measuring device. The results showed that $\mathrm{SiC}$ can serve as an interlayer between the carbon/carbon composites and Ti6Al4V. The SiC/Ti6Al4V coatings covered the carbon/carbon composites uniformly with spherical morphology. The coatings improved the surface wettability of carbon/carbon composites with the contact angle of water decreasing from $85.7 \pm 4.1^{\circ}$ to $26.5 \pm 0.1^{\circ}$.
\end{abstract}

\section{Introduction}

Carbon/carbon $(\mathrm{C} / \mathrm{C})$ composites play an important role in biomedical application because they possess excellent biocompatibility and mechanical properties $[1,2]$. Their elastic modulus is close to that of human bones, thus avoiding the bone resorption caused by the effect of stress shielding $[3,4]$. The cell culture experiment confirms that the C/C composites are supportive for the cell adhesion and growth [5]. However, poor surface wettability of the $\mathrm{C} / \mathrm{C}$ composites reduces protein absorption and cell attachment thus reducing the osteoconductivity and reducing bone regeneration. Many studies have been made to improve the surface wettability of $\mathrm{C} / \mathrm{C}$ composites. Zhao et al. have reported the ultraassisted anodic oxidation treatment for $\mathrm{C} / \mathrm{C}$ composites to improve the surface wettability. They found that some hydrophilic groups were grafted on the surface of $\mathrm{C} / \mathrm{C}$ composites and the surface wettability was improved [6]. Xiong et al. have made surface modification to $\mathrm{C} / \mathrm{C}$ composites by hydrothermal treatment in an autoclave containing ammonium persulfate solution. They found that the percentage of oxygen atoms on the surface of $\mathrm{C} / \mathrm{C}$ composites was significantly increased [7].
The above-mentioned methods to improve the surface wettability are mainly surface oxidation. In this work, $\mathrm{SiC} / \mathrm{Ti} 6 \mathrm{Al} 4 \mathrm{~V}$ coatings were applied on $\mathrm{C} / \mathrm{C}$ composites to improve the surface wettability of water. The $\mathrm{SiC}$ interlayer was used to bond both the $\mathrm{C} / \mathrm{C}$ composites and the Ti6Al4V, and the Ti6Al4V was used to improve surface wettability of the C/C composites. The Ti6Al4V has been widely applied to both dental implantology and orthopedic replacement. This is an inert biomaterial with excellent biocompatibility, boneimplant integration, and unique resistance to corrosion.

\section{Experimental}

Small specimens $(8 \mathrm{~mm} \times 8 \mathrm{~mm} \times 2 \mathrm{~mm})$ were cut from bulk two dimensional C/C composites with a density of $1.82 \mathrm{~g} / \mathrm{cm}^{3}$ and a porosity of $8.10 \%$. The preform of the $\mathrm{C} / \mathrm{C}$ composites was needle-punched carbon fiber felt. According to the different characterizations under polarizing microscope, the pyrolytic carbon was classified into three structures, including smooth laminar structure, rough laminar structure, and isotropic structure $[8,9]$. In this work, the pyrolytic carbon 


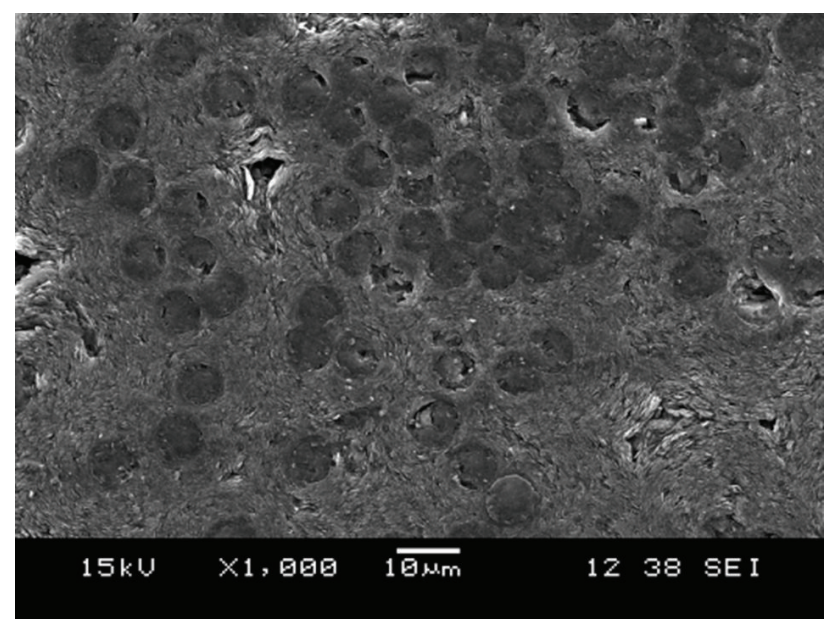

FIGURE 1: SEM micrograph of the C/C composites.

TABLE 1: Parameters of the magnetron sputtering process.

\begin{tabular}{lccc}
\hline $\begin{array}{l}\text { Distance between the } \\
\text { sample and target }(\mathrm{mm})\end{array}$ & $\begin{array}{c}\text { Sputtering } \\
\text { power }(\mathrm{W})\end{array}$ & $\begin{array}{c}\text { Ar pressure } \\
(\mathrm{Pa})\end{array}$ & $\begin{array}{c}\text { Sputtering } \\
\text { time (hour) }\end{array}$ \\
\hline 60 & 500 & 3 & 5
\end{tabular}

shows smooth laminar structures. The specimens were handabraded with 400 grit $\mathrm{SiC}$ paper, ultracleaned in turn by acetone, ethanol, and distilled water, and dried at $353 \mathrm{~K}$ for $5 \mathrm{~h}$. The SEM micrographs of the $\mathrm{C} / \mathrm{C}$ composites were shown in Figure 1. The surface roughness of the $\mathrm{C} / \mathrm{C}$ composites was $R_{\mathrm{a}}=1.6 \pm 0.1 \mu \mathrm{m}$.

$\mathrm{SiC}$ interlayers were prepared by pack cementation technology. Pack cementation technology is carried out at high temperatures by embedding the substrate in powders composed of depositing material and inert filler. Using this method, the coating can be applied on the substrate through vapor transport and diffusion. The powders for preparing $\mathrm{SiC}$ were $60-80 \mathrm{wt} \% \mathrm{Si}, 10-25 \mathrm{wt} \%$ graphite, and $5-15 \mathrm{wt} \%$ $\mathrm{Al}_{2} \mathrm{O}_{3}$. In this work, alumina is used as sintering aids in the preparation of $\mathrm{SiC}$. The alumina not only can improve density of the $\mathrm{SiC}$ but also can decrease the sintering temperature. The specimens and pack powders were put in a graphite crucible and heat-treated at $2173 \mathrm{~K}$ for $2 \mathrm{~h}$ in an argon protective atmosphere to form the $\mathrm{SiC}$ interlayers.

After the preparation of $\mathrm{SiC}$ interlayers, Ti6 Al4V coatings were prepared on $\mathrm{SiC}$ coated $\mathrm{C} / \mathrm{C}$ composite specimens using an ultrahigh vacuum magnetron sputtering machine. Before deposition, the surface of $\mathrm{SiC}$ coated $\mathrm{C} / \mathrm{C}$ composites was cleaned with $\mathrm{Ar}^{+}$for $1 \mathrm{~h}$ to remove the impurities. The target used in this work was purchased from Baoji Titanium Industry Co., Ltd, China. The parameters of the magnetron sputtering process were listed in Table 1.

The surface morphology and crystalline of the coatings were analyzed by a SUPRA55 scanning electron microscope (SEM) equipped with energy dispersive spectroscopy (EDS) and a Philips X'pert PRO X-ray diffraction (XRD).

The surface roughness of the $\mathrm{SiC}$ interlayer was tested by a Lasertec $\mathrm{C} 130$ laser confocal scanning microscope. The

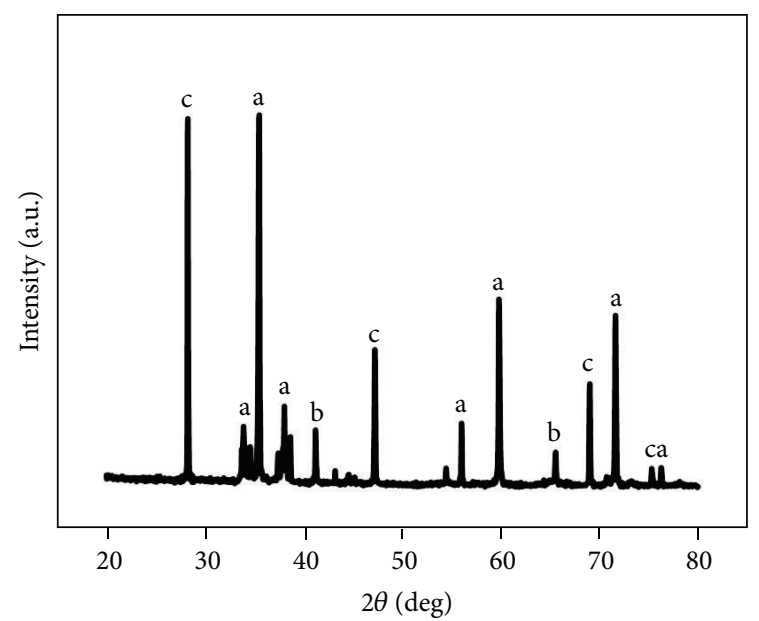
(a) $\alpha-\mathrm{SiC}$
(b) $\beta-\mathrm{SiC}$
(c) $\mathrm{Si}$

FIGURE 2: XRD pattern of the interlayer prepared by pack cementation.

two dimensional surface profiles were recorded. To obtain the average surface roughness of $R_{\mathrm{a}}$, measurements were performed on five samples and five positions were tested for each sample.

Surface wettability of $\mathrm{C} / \mathrm{C}$ composite specimens and the $\mathrm{SiC} / \mathrm{Ti} 6 \mathrm{Al} 4 \mathrm{~V}$ coatings were analyzed using a video-based contact angle measuring device (Dataphysics OCA20) by testing the contact angle of distilled water. Six measurements were taken for each specimen and an average contact angle was calculated. The tested data were presented as the mean and standard deviation. The Student's $t$-test was applied for analytical statistics $[10,11]$. Differences between each sample were considered statistically significant at a $P$ value of $<0.05$.

\section{Results and Discussion}

Figure 2 shows XRD pattern of interlayer prepared by pack cementation process. It shows the diffraction peaks of $\alpha$ $\mathrm{SiC}, \beta-\mathrm{SiC}$, and $\mathrm{Si}$. The strong peaks for $\alpha$-SiC are observed, suggesting that the interlayers are mainly composed of $\alpha-\mathrm{SiC}$ phase.

Figure 3 shows the SEM micrograph and surface roughness curve of the $\mathrm{SiC}$ interlayers. The $\mathrm{SiC}$ interlayers cover the surface of $\mathrm{C} / \mathrm{C}$ composites entirely with a dense morphology without visible cracks. The surface of the $\mathrm{SiC}$ interlayers has rough morphology. The surface roughness curve demonstrates that the surface profile of the $\mathrm{SiC}$ interlayers fluctuates around the datum line with large fluctuation amplitude. The average surface roughness value of the $\mathrm{SiC}$ interlayer is $R_{\mathrm{a}}=$ $2.6 \pm 0.2 \mu \mathrm{m}$, which is higher than the surface roughness of uncoated C/C composites $\left(R_{\mathrm{a}}=1.6 \pm 0.1 \mu \mathrm{m}\right)$ [12]. The rough surface of the $\mathrm{SiC}$ interlayers may favor the bonding to the following Ti6Al4V coatings.

Figure 4 shows the XRD pattern, EDS result, and SEM micrograph of Ti6Al4V coatings prepared by magnetron 


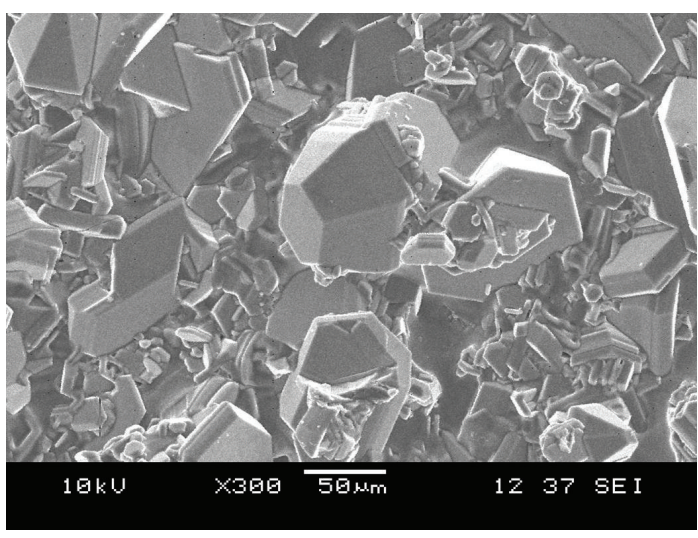

(a)

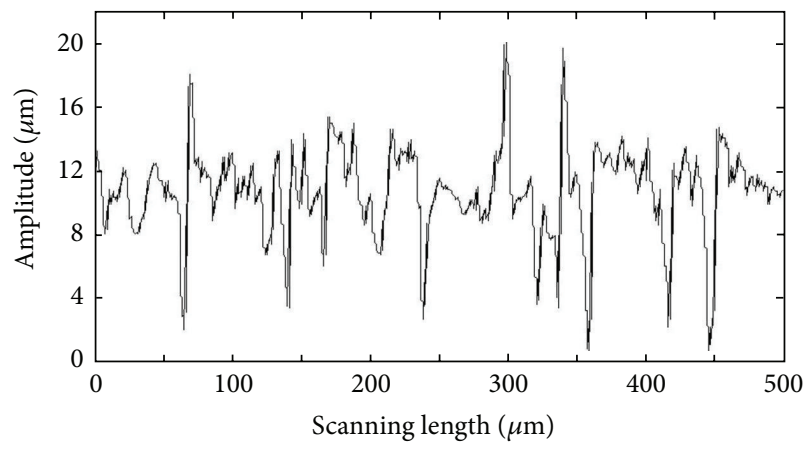

(b)

FIgURE 3: (a) SEM micrograph and (b) surface roughness curve of the SiC interlayers.

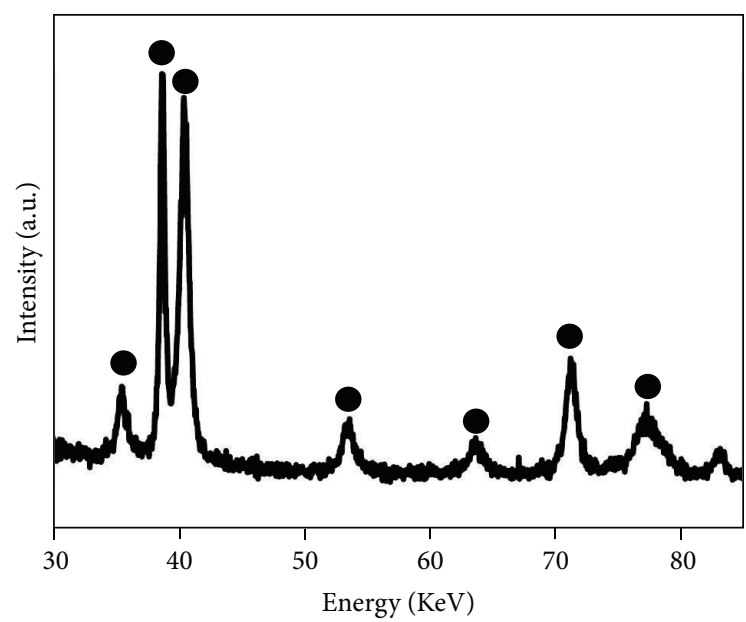

hcp Ti

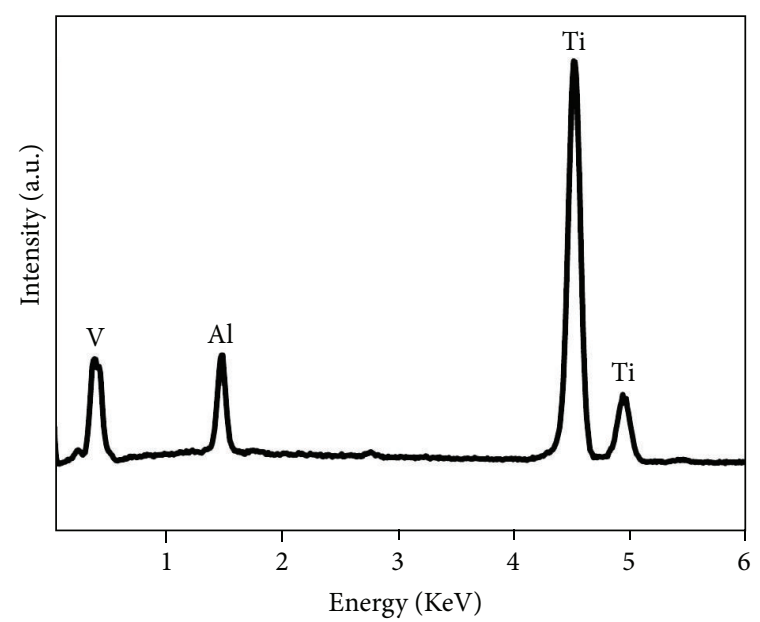

(b)

(a)

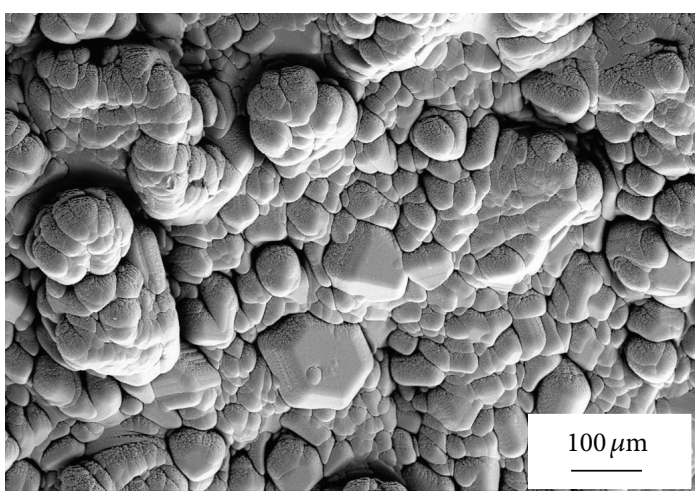

(c)

Figure 4: (a) XRD pattern, (b) EDS result, and (c) SEM micrograph of the Ti6Al4V coatings.

sputtering. The XRD pattern shows that the coatings are composed of hexagonal closed-packed (hcp) $\alpha$-Ti phase. The EDS result shows that the coatings are composed of
Ti element, $\mathrm{Al}$ element, and $\mathrm{V}$ element. It also confirms the successful formation of the Ti6Al4V coatings. The SEM micrograph shows that the Ti6Al4V coatings fully cover the 


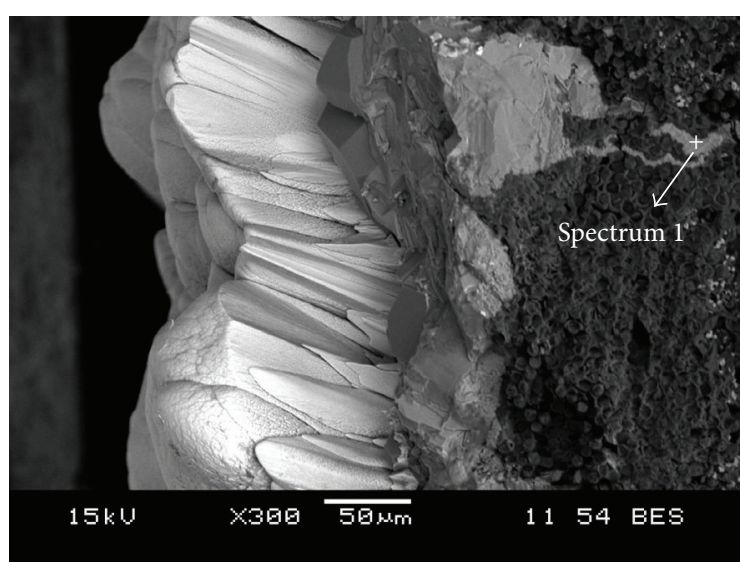

(a)

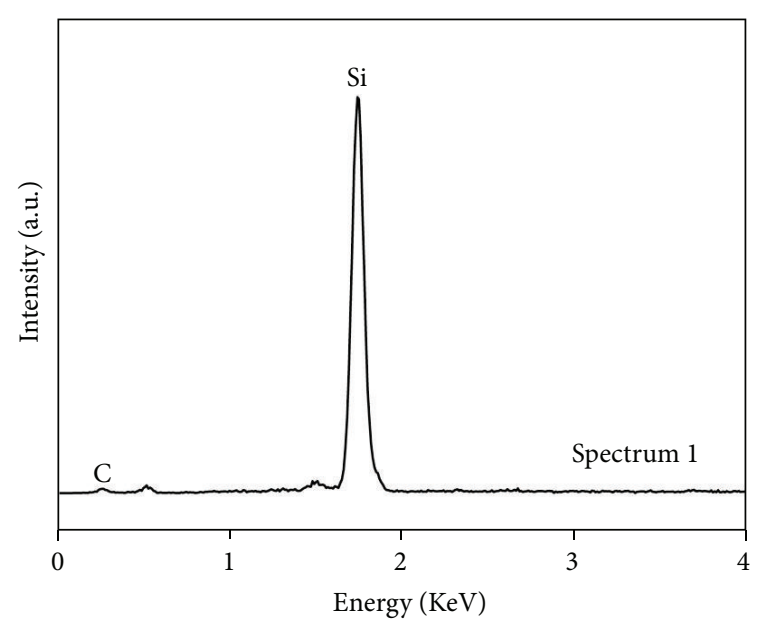

(b)

FIgure 5: (a) Cross-section micrograph and (b) EDS result of the SiC/Ti6Al4V coatings.

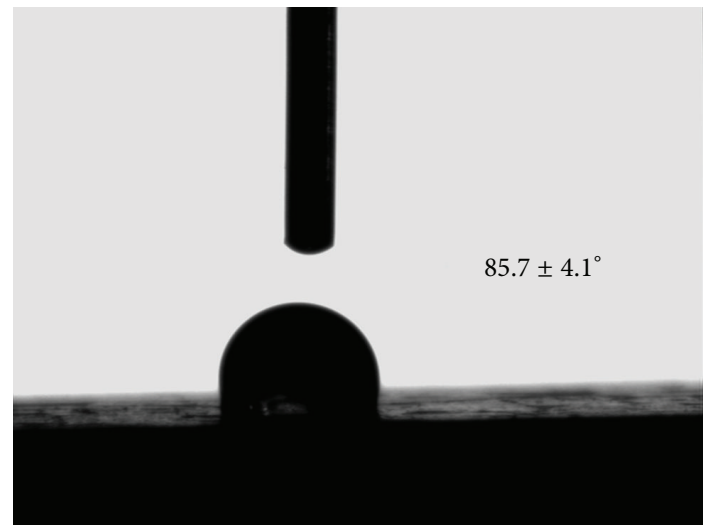

(a)

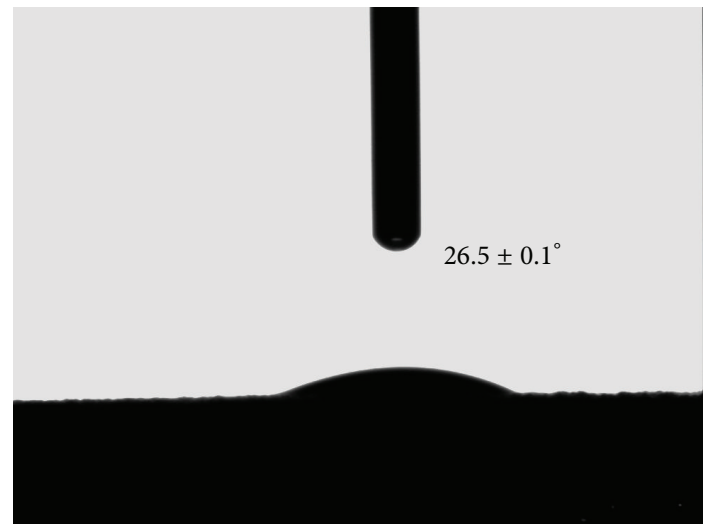

(b)

FIGURE 6: The photos and values of contact angle toward distilled water for (a) uncoated C/C composites and (b) SiC/Ti6 Al4V coatings.

$\mathrm{SiC}$ interlayer coated $\mathrm{C} / \mathrm{C}$ composites. The deposition of the Ti6Al4V coatings is primarily following the contours of the $\mathrm{SiC}$ interlayers.

Figure 5 shows the cross-section micrograph and EDS result of the SiC/Ti6Al4V coatings. The cross-section micrograph shows that the thickness of the coatings is about $130 \mu \mathrm{m}$. The SiC interlayers may be formed by the reaction of $\mathrm{Si}$ with the graphite powder or $\mathrm{Si}$ with the $\mathrm{C}$ on the surface of $\mathrm{C} / \mathrm{C}$ composites. The $\mathrm{SiC}$ interlayer may bond to the $\mathrm{C} / \mathrm{C}$ composites by chemical reaction of $\mathrm{Si}$ with the $\mathrm{C}$ on the surface of the $\mathrm{C} / \mathrm{C}$ composites. The EDS result confirms the infiltration of $\mathrm{SiC}$ into the inside of $\mathrm{C} / \mathrm{C}$ composites. In addition, the $\mathrm{SiC}$ interlayer also forms a bonding to the Ti6Al4V coatings tightly due to its rough surface morphology. No obvious gap between the $\mathrm{SiC}$ interlayer and Ti6Al4V coatings is observed.

Figure 6 shows the photos and values of contact angle toward distilled water for uncoated $\mathrm{C} / \mathrm{C}$ composites and the $\mathrm{SiC} / \mathrm{Ti} 6 \mathrm{Al} 4 \mathrm{~V}$ coatings. The extension of the distilled water on $\mathrm{SiC} / \mathrm{Ti} 6 \mathrm{Al} 4 \mathrm{~V}$ coatings is better than that on uncoated $\mathrm{C} / \mathrm{C}$ composites. The contact angles of water are $26.5 \pm 0.1^{\circ}$ for $\mathrm{SiC} / \mathrm{Ti} 6 \mathrm{Al} 4 \mathrm{~V}$ coatings and $85.7 \pm 4.1^{\circ}$ for uncoated $\mathrm{C} / \mathrm{C}$ composites. The significant decrease of contact angles is found between the uncoated $\mathrm{C} / \mathrm{C}$ composites and SiC/Ti6Al4V coatings $(P<0.001)$, suggesting a remarkably improvement of surface wettability of water. The water contact angle is the angle where a water/vapor interface meets a solid surface. It quantifies the wettability of a solid surface by water. As the tendency of a water drop to spread out over a solid surface increases, the contact angle decreases. Thus, the contact angle provides an inverse measure of wettability. In the field of biomaterial researches, an improvement in surface wettability of biomaterials can promote cell survival and attachment. Thus, a decreased water contact angle indicated the improved cell response and favorable osteoconducive behavior.

\section{Conclusions}

SiC/Ti6Al4V coatings were applied on C/C composites by combination of pack cementation and magnetron sputtering 
technique. The $\mathrm{SiC}$ can serve as an interlayer between the $\mathrm{C} / \mathrm{C}$ composites and Ti6Al4V. The SiC/Ti6Al4V coatings significantly improve the surface wettability of $\mathrm{C} / \mathrm{C}$ composites with the contact angle of water decreasing from $85.7 \pm 4.1^{\circ}$ to $26.5 \pm 0.1^{\circ}$.

\section{Conflict of Interests}

All the authors of this paper do not have a direct financial relation with the commercial identity mentioned in this paper that might lead to a conflict of interests for any of the authors.

\section{Acknowledgments}

This work is supported by the following projects: Project supported by the National Natural Science Foundation of China (no. 51202194), Project supported by the China Postdoctoral Science Foundation (Grant no. 2011M501473), Project supported by the Research Fund of the State Key Laboratory of Solidification Processing (NWPU), China (Grant no. 11-BZ2012).

\section{References}

[1] T. Fu, L. P. He, Y. Han, K.-W. Xu, and Y.-W. Mai, "Induction of bonelike apatite on carbon-carbon composite by sodium silicate," Materials Letters, vol. 57, no. 22-23, pp. 3500-3503, 2003.

[2] G. H. Wang, S. Yu, S. H. Zhu et al., "Biological properties of carbon/carbon implant composites with unique manufacturing processes," Journal of Materials Science: Materials in Medicine, vol. 20, no. 12, pp. 2487-2492, 2009.

[3] X. B. Xiong, C. C. Chu, J. F. Huang, X. Zeng, and Z. Zou, "Preparation and characterization of fluoridated hydroxyapatite coatings on HT-C/C composites," Surface and Coatings Technology, vol. 206, no. 8-9, pp. 2535-2540, 2012.

[4] L. L. Zhang, H. J. Li, K. Z. Li et al., "Effect of surface roughness of carbon/carbon composites on osteoblasts growth behaviour," Journal of Inorganic Materials, vol. 23, no. 2, pp. 341-345, 2008.

[5] V. Pesakova, K. Smetana, M. Sochor, H. Hulejová, and K. Balík, "Biological properties of the intervertebral cages made of titanium containing a carbon-carbon composite covered with different polymers," Journal of Materials Science: Materials in Medicine, vol. 16, no. 2, pp. 143-148, 2005.

[6] X. N. Zhao, H. J. Li, M. D. Chen et al., "Strong-bonding calcium phosphate coatings on carbon/carbon composites by ultrasound-assisted anodic oxidation treatment and electrochemical deposition," Applied Surface Science, vol. 258, no. 12, pp. 5117-5125, 2012.

[7] X. B. Xiong, X. R. Zeng, C. L. Zou, and J.-Z. Zhou, "Strong bonding strength between $\mathrm{HA}$ and $\left(\mathrm{NH}_{4}\right)_{2} \mathrm{~S}_{2} \mathrm{O}_{8}$-treated carbon/carbon composite by hydrothermal treatment and induction heating," Acta Biomaterialia, vol. 5, pp. 1785-1790, 2009.

[8] H. O. Pierson and M. L. Lieberman, "The chemical vapor deposition of carbon on carbon fibers," Carbon, vol. 13, no. 3, pp. 159-166, 1975.

[9] M. L. Lieberman and H. O. Pierson, "Effect of gas phase conditions on resultant matrix pyrocarbons in carbon/carbon composites," Carbon, vol. 12, no. 3, pp. 233-241, 1974.
[10] J. Lincks, B. D. Boyan, C. R. Blanchard et al., "Response of MG63 osteoblast-like cells to titanium and titanium alloy is dependent on surface roughness and composition," Biomaterials, vol. 19, no. 23, pp. 2219-2232, 1998.

[11] C. Wirth, B. Grosgogeat, C. Lagneau, N. Jaffrezic-Renault, and L. Ponsonnet, "Biomaterial surface properties modulate in vitro rat calvaria osteoblasts response: roughness and or chemistry?" Materials Science and Engineering C, vol. 28, no. 5-6, pp. 9901001, 2008.

[12] L. L. Zhang, H. J. Li, J. H. Lu et al., "Surface characteristic and cell response of CVD SiC coating for carbon/carbon composites used for hip arthroplasty," Surface and Interface Analysis, vol. 44, no. 10, pp. 1319-1323, 2012. 

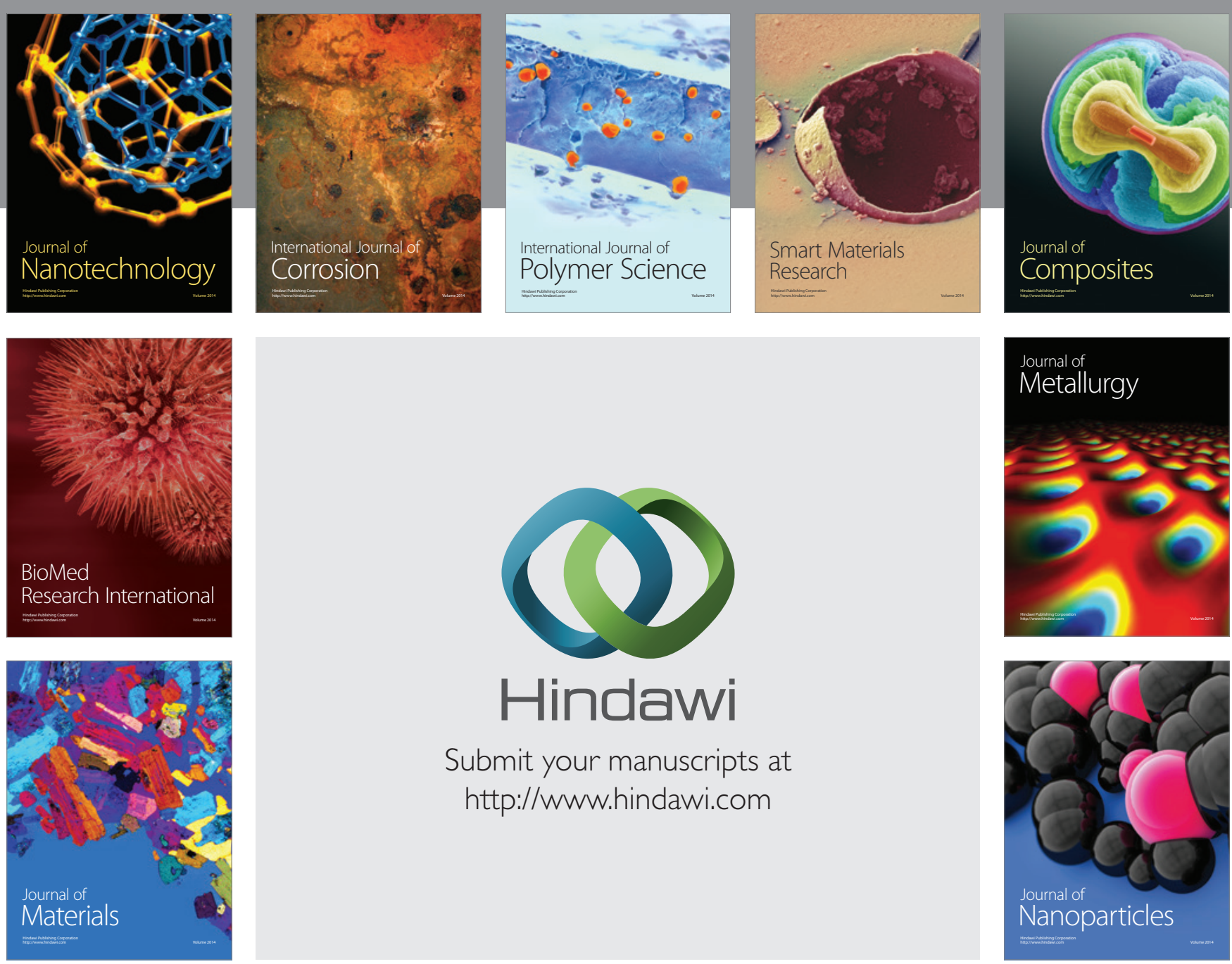

Submit your manuscripts at http://www.hindawi.com
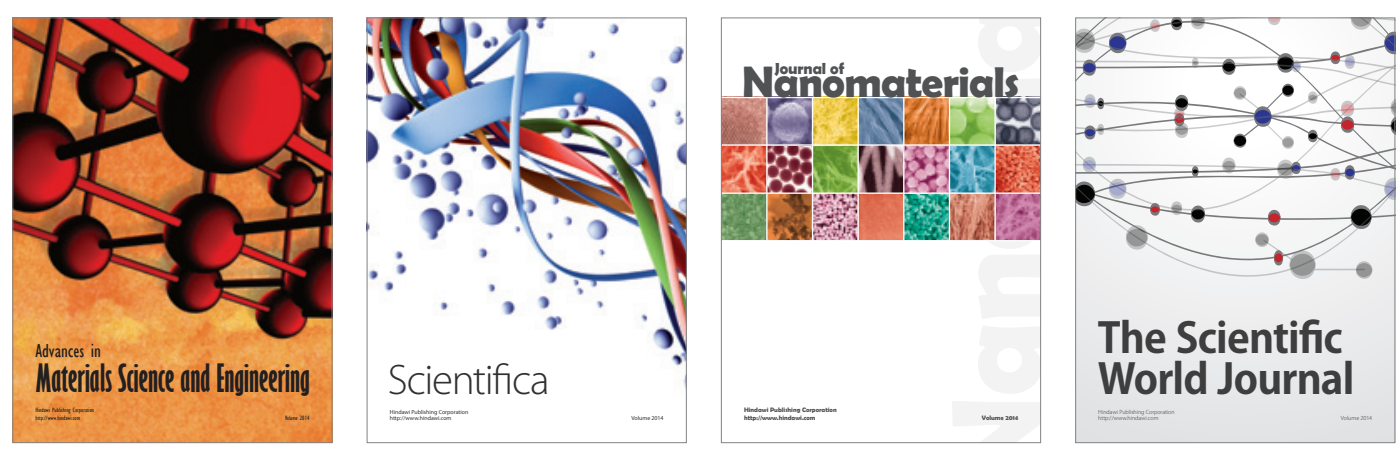

\section{The Scientific World Journal}
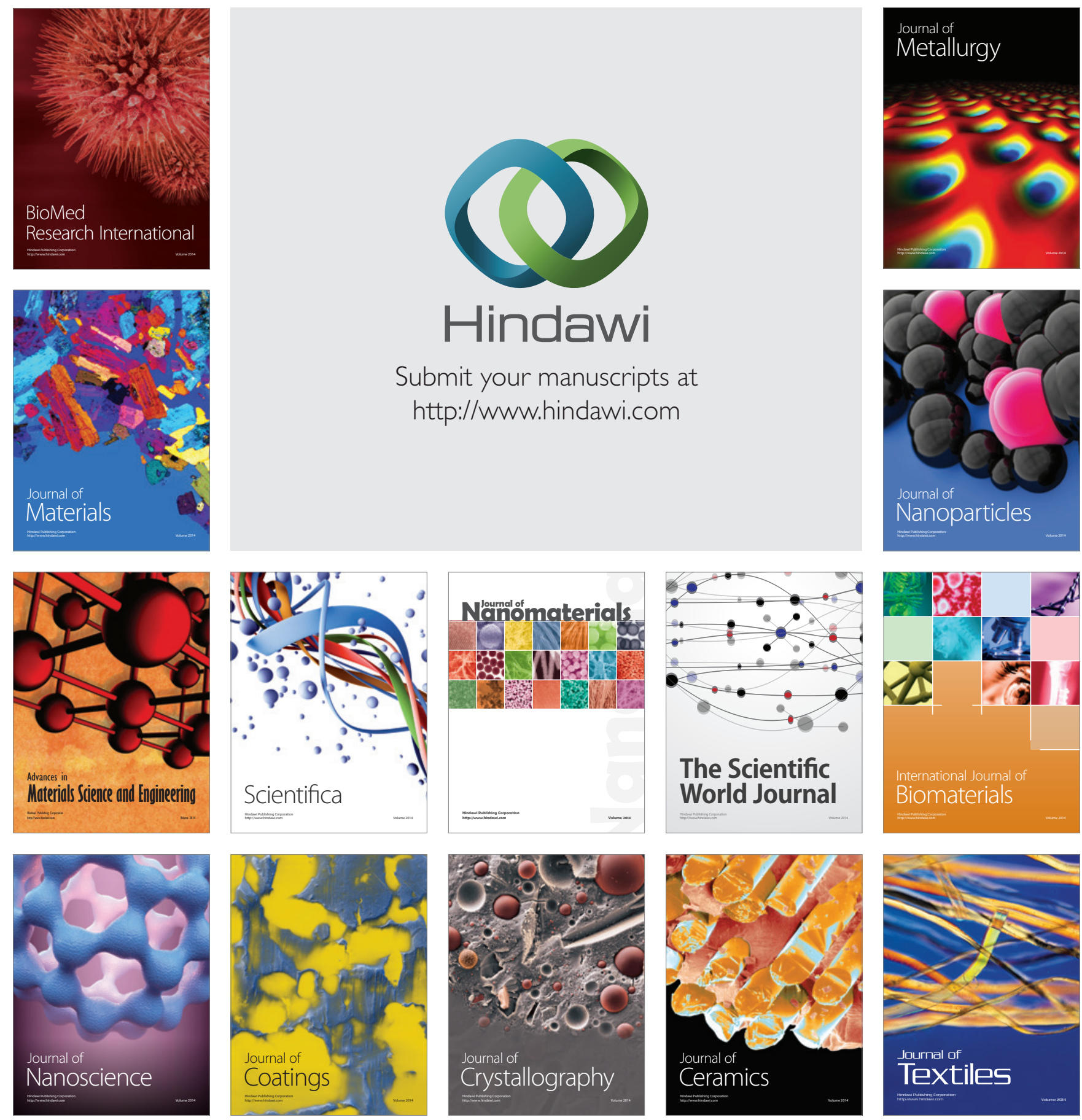